\title{
PERAN PESANTREN AL-BUKHORI PONOROGO DALAM MENINGKATKAN RELIGIUSITAS MASYARAKAT MUSLIM PEDESAAN MELALUI PENCAK SILAT NAHDLATUL ULAMA' PAGAR NUSA GASMI
}

\author{
Ahmad Muslih \\ Institut Agama Islam Sunan Giri Ponorogo \\ muslih86@gmail.com
}

\begin{abstract}
Abstrak
Fenomena perubahan sosial-keagamaan yang terjadi di dukuh Pilang, desa Tulung, kecamatan Sampung kabupaten Ponorogo karena adanya peran pesantren Al-Bukhori Ponorogo dalam meningkatkan religiusitas dan spirirualitas masyarakat muslim melalui pencak silat NU Pagar Nusa Gasmi. Perubahan tersebut tidak merubah kondisi fisik di lingkungan sekitar tetapi karena ada keterkaitan kegiatan-kegiatan Pencak Silat NU Pagar Nusa GASMI dengan masyarakat muslim yang berpengaruh terhadap kehidupan religiusitas dan spiritualitas yang secara langsung atau tidak langsung membawa dampak tersendiri dalam kehidupan bermasyarakat. Analisis penelitian menggunakan teori strukturasi Anthony Giddens yang menjelaskan konsep agen dan struktur, ruang dan waktu serta hubungan struktur dengan praktik sosial. Metodologi peneltian menggunakan deskriptif dengan pendekatan kualitatif dan pengumpulan data menggunakan observasi yakni mengamati kondisi lingkungan sekitar pesantren Al-Bukhori Ponorogo dan berbagai praktik sosial-keagamaan agen yang berkaitan dengan konteks penelitian, wawancara terhadap informan utama dan tambahan serta berbagai dokumentasi. Berdasarkan hasil analisis data menunjukkan bahwa terdapat tiga orang agen dari masyarakat di dukuh Pilang yang mengawali perubahan dengan kesadaran diskursifnya. Perannya dalam perubahan sosial dengan sosialisasi, pemberian materi dan berkoordinasi. Struktur berasal dari masyarakat tersebut beserta praktik sosial-keagamaan sesuai kesadaran praktis dan diskursifnya, peran Pemda Ponorogo dan pemerintah desa Tulung melalui kebijakan strukturalnya. Hubungan antara agen dengan struktur terjadi melalui skema dominasi (penguasaan agen terhadap struktur), signifikansi (ajakan agen pada struktur) dan legitimasi (pembenaran atas upaya agen oleh struktur).
\end{abstract}

Kata kunci: peran pesantren, pagar nusa gasmi, religiusitas, strukturisasi perubahan sosial.

Abstract

The phenomenon of socio-religious change that occurred in Pilang hamlet, Tulung village, Sampung sub-district, Ponorogo district was due to the role of the Al-Bukhori Ponorogo Islamic boarding school in increasing the religiosity and spirituality of the Muslim community through the NU Pagar Nusa Gasmi pencak silat. These changes do not change the physical conditions in the surrounding environment, but because there is a connection between NU Pagar Nusa GASMI's Pencak Silat activities with the Muslim community which has an effect on religious life and spirituality which directly or indirectly brings its own impact in social life. The research analysis uses Anthony Giddens' structuration theory which explains the concept of agency and structure, space and time and the relationship of structure to social practice. The research methodology uses a descriptive qualitative approach and data collection uses observation, namely observing environmental conditions 
around the Al-Bukhori Ponorogo Islamic boarding school and various socio-religious practices of agents related to the research context, interviews with key and additional informants and various documentations. Based on the results of data analysis, it shows that there are three agents from the community in Pilang hamlet who initiated the change with their discursive awareness. Its role in social change is by socializing, providing materials and coordinating. The structure comes from the community along with socio-religious practices according to their practical and discursive awareness, the role of the Ponorogo Regional Government and the Tulung village government through their structural policies. The relationship between the agent and the structure occurs through the scheme of domination (the agent's control over the structure), significance (the agent's invitation to the structure) and legitimacy (justification for the agent's efforts by the structure).

Keywords: the role of pesantren, the fence of Nusa Gasmi, religiosity, structuring social change.

\section{PENDAHULUAN}

Salah satu lembaga pendidikan yang mempunyai kekhasan tersendiri dan berbeda dengan lembaga pendidikan yang lainnya adalah pesantren (Saleh : 2000). Ditinjau dari segi historisnya pesantren merupakan bentuk lembaga pribumi tertua yang berada di Indonesia dan kegiatannya berawal dari pengajian kitab. Sebagaimana yang diungkapkan oleh H.M. Yakup bahwa pondok pesantren secara implisit sebagai lembaga pendidikan Islam tradisional, tidak berarti seluruh pondok pesantren itu tertutup dengan inovasi. Pada zaman penjajahan Belanda memang mereka menutup diri dari segala pengaruh luar terutama pengaruh barat yang non Islami. Namun dilain pihak pondok pesantren dengan figur kyainya telah berhasil membangkitkan nasionalisme, mempersatukan antar sukusuku yang seagama bahkan menjadi benteng yang gigih melawan penjajahan (Yaqub :1984).

Keberadaan pesantren sebagai lembaga pendidikan Islam sangat kental dengan karakteristik Indonesia yang memiliki nilai-nilai strategis dalam pengembangan masyarakat Indonesia. Keberadaan pondok pesantren sebagai wadah untuk memperdalam agama sekaligus sebagai pusat penyebaran agama Islam sejalan dengan gelombang pertama dari proses pengislaman di daerah Jawa yang berakhir sekitar abad ke-16 (Galba : 2004). Pondok pesantren adalah hasil penyerapan akulturasi dari masyarakat Indonesia terhadap kebudayaan Hindu-Buddha dan kebudayaan Islam yang kemudian menjelmakan suatu lembaga yang lain dan baru dengan warna Indonesia yang berbeda dengan pesantrenpesantren yang dijumpai di India dan di Arab (Yusuf : 2010).

Pesantren merupakan pusat kegiatan keagamaan murni (tafaqquh fi al-din) untuk penyiaran agama Islam sedangkan menurut Abdurrahman Wahid (Gus Dur) pesantren adalah sebuah kehidupan yang unik, sebagaimana dapat disimpulkan dari gambaran lahiriahnya. Pesantren adalah sebuah kompleks yang lokasi umumnya terpisah dari kehidupan sekitarnya. Dalam kompleks itu terdiri dari beberapa buah bangunan yaitu rumah kediaman pengasuh (kiai), sebuah surau atau masjid, tempat pengajaran (madrasah atau sekolah) dan asrama tempat tinggal para siswa pesantren (santri) (Wahid: 2001).

Pesantren sejak awal tumbuh dan berkembang diberbagai daerah Indonesia telah dikenal sebagai lembaga keislaman yang memiliki nilai-nilai strategis dalam pengembangan masyarakat Indonesia. Sejak kemunculannya ratusan tahun yang lalu telah menjangkau 
berbagai lapisan masyarakat khususnya masyarakat muslim. Kehadiran pesantren telah diakui sebagai lembaga pendidikan yang turut serta mencerdaskan kehidupan bangsa. Pesantren sebagai lembaga pendidikan tradisional Islam yang meliputi dua aspek yaitu: Pertama pemberian pengajaran dengan struktur, metode, dan literatur tradisional. Pemberian pengajaran tradisional ini dapat berupa pendidikan formal di sekolah atau madrasah dengan jenjang pendidikan yang bertingkat-tingkat maupun pemberian pengajaran dengan sistem halaqah dalam bentuk pengajian weton dan sorogan. Kedua, pemeliharaan tata nilai tertentu untuk memudahkan dapat dinamai subkultur pesantren. Tata nilai ini ditekankan pada fungsi mengutamakan beribadah sebagai pengabdian dan memuliakan guru sebagai jalan untuk memperoleh pengetahuan agama dan menetapkan pandangan hidupnya sendiri yang bersifat khusus pesantren, berdiri atas landasan pendekatan ukhrawi pada kehidupan dan ditandai oleh ketundukan mutlak kepada ulama. Adapun ciri utama dari sistem pendidikan tradisional adalah banyak diberikan pengajaran diluar kurikulum formalnya.

Pondok pesantren melahirkan para juru dakwah, para mualim, ustadz, para kyai, tokoh-tokoh masyarakat bahkan yang memiliki profesi sebagai pedagang, pengusaha ataupun banyak bidang lainnya sehingga dapat dinyatakan sesungguhnya bahwa pendidikan pondok pesantren pada proses pendidikan yang mengarah kepada pembentukan etika, moral ataupun rohaniah. Pondok pesantren disebut reproduksi ulama karena di pesantren ulama dibentuk, ulama berarti orang yang memiliki pengetahuan. Karakter ulama diatas belumlah berhenti dengan berhasilnya santri tersebut dalam memperoleh ilmu pengetahuan ditambah dengan semangat pengabdian di masyarakat baik dalam bentuk pengajaran atau pemberian ceramah. Pondok pesantren bukan sekedar penguasaan ilmu-ilmu agama melainkan juga sebagai media penyebaran agama Islam. Ada tiga fungsi pondok pesantren yaitu transmisi dan transfer ilmu-ilmu Islam, memelihara tradisi Islam dan reproduksi ulama (Nizar : 2013). Pengaruh yang tumbuh akibat adanya sebuah pondok pesantren yang ada di lingkungan suatu masyarakat dapat dilihat dari segi moral, akhlak, gaya hidup bahkan perekonomian masyarakat sekitar pondok pesantren yang jelas berbeda dari masyarakat yang tidak tinggal berdekatan dengan pondok. Religius atau bersifat agamis didefiniskan sebagai perilaku yang patuh dalam melaksanakan ajaran agama yang dianut, toleran terhadap pelaksanaan ibadah agama lain. Karakter religius ini sangat dibutuhkan oleh masyarakat untuk menghadapi perubahan zaman dan degradasi moral.

Pondok Pesantren Al-Bukhori yang terletak di dukuh Pilang, desa Tulung, Kecamatan Sampung Kabupaten Ponorogo, tidak hanya berperan dalam bidang pendidikan saja akan tetapi juga berperan dalam meningkatkan nilai religius masyarakat muslim pedesaaan. Keterkaitan kegiatan-kegiatan santri dengan masyarakat muslim pedesaaan sekitarnya berpengaruh terhadap kehidupan religiusitas secara langsung atau tidak langsung membawa dampak tersendiri dalam kehidupan bermasyarakat. Kyai Mukrim Abdullah selaku pimpinan Ponpes Al-Bukhori menuturkan diantara kegiatan rutin yang dilestarikan di pondok pesantren Al-Bukhori adalah pembacaan Manakib Sulthonul Auliya Syaikh Abdul Qodir Al Jaelani atau sering disebut manakiban yang dilaksanakan pada malam tanggal 11 bulan hijriah, kegiatan khususiyah setiap Selasa Legi, kegiatan salat jama'ah di masjid, baca al-Quran, salat Jum'at berjamaah, dan GASMI (Gerakan Aksi Silat Muslimin Indonesia) yang merupakan lembaga pencak silat dibawah naungan Pencak Silat Nahdlatul Ulama' Pagar Nusa (PSNU Pagar Nusa) dan tergabung dalam Ikatan Pencak Silat Indonesia (IPSI).

Pencak Silat merupakan warisan dari kebudayaan kerajaan-kerajaan pada zaman dulu. 
Dan seiring dengan perkembangan zaman banyak pula berdirinya organisasi pencak silat. Beberapa diantaranya yaitu Tapak Suci (TS), Kera Sakti (KS), Perisai Diri (PD), Persinas Asad (PA), Joko Tole (JT), Sawunggaling, Pencak Organisasi (PO), Merpati Putih (MP), Persaudaraan Setia Hati Terate (PSHT), Nur Harias (NH), Pencak Silat Nahdlatul Ulama Pagar Nusa (PS NU PN) dan lain sebagainya.

Awal sejarah berdirinya GASMI pertama kali diperkenalkan di Pondok Pesantren Lirboyo Kediri Jawa Timur yang dikembangkan oleh KH. Agus Maksum Jauhari atau lebih akrab disapa Gus Maksum. Dari awal berdirinya hingga sekarang, GASMI terus berkembang diberbagai daerah di pulau Jawa, bahkan sampai di luar pulau Jawa. Di Kabupaten Ponorogo GASMI pertama kali diperkenalkan di Pondok Pesantren Al-Bukhori yang beralamatkan di dukuh Pilang, desa Tulung, kecamatan Sampung, kabupaten Ponorogo pada tahun 1971-an yang ketika itu dibawa Simbah Kyai Mukrim Abdullah muda dari Pondok Pesantren Lirboyo Kediri. Selain menjadi santri yang belajar ilmu agama beliau juga belajar ilmu bela diri dan langsung dibawah bimbingan Gus Maksum sebagai pendiri GASMI. Selain menjadi guru besar Gasmi, Gus Maksum juga mendapat amanah menjadi ketua umum pertama Pimpinan Pusat Pencak Silat Nahdlatul Ulama Pagar Nusa (PP PSNU PAGAR NUSA).

\section{Metode Penelitian}

Penelitian ini berbentuk penelitian kualitatif yakni penelitian yang menggunakan katakata dalam menjelaskan temuan penelitian dan menganalisisnya. Penelitian kualitatif berbeda dengan kuantitatif yang menggunakan data berupa angka sebagai hasil temuan dan menganalisis temuan penelitian. Penelitian kualitatif sangat cocok digunakan untuk memahami fenomena sosial, masalah atau gejala dalam manusia dengan mengumpulkan sebanyak mungkin fakta mendalam, data disajikan dalam bentuk verbal, bukan dalam bentuk angka. Alasannya karena dalam pengumpulan data pada penelitian ini terjadi interaksi antara peneliti dengan sumber data. Di samping itu metode kualitatif paling cocok digunakan untuk mengembangkan teori yang dibangun melalui data yang diperoleh di lapangan.

Pendekatan kualitatif yaitu data yang terkumpul berbentuk kata-kata, gambar dan bukan angka-angka. Kalau ada bentuk dalam angka-angka, sifatnya hanya sebagai penunjang. Data yang diperoleh meliputi transkrip, dokumen wawancara, catatan lapangan, foto, dokumen pribadi, dan lain-lain (Danim: 2002). Penelitian ini berlokasi di Pondok Pesantren Al-Bukhori yang terletak di dukuh Pilang, desa Tulung, kecamatan Sampung, kabupaten Ponorogo. Informan yang dijadikan subyek dalam penelitian ini adalah Kyai Mukrim Abdullah, S. Beni M, Amrul Ardiansyah, dan Irfan M. Pemilihan informan menggunakan teknik purposive, maksudnya adalah informan dipilih berdasarkan karakteristik dan kapasitas informan dalam memberikan keterangan terkait tentang peran pesantren Al-Bukhori Ponorogo dalam meningkatkan religiusitas masyarakat muslim di dukuh Pilang desa Tulung kecamatan Sampung kabupaten Ponorogo melalui Pencak Silat Nahdlatul Ulama' Pagar Nusa GASMI.

\section{HASIL PEMBAHASAN}

\section{Peran Sosial-Keagamaan Pesantren Al-Bukhori Ponorogo}

Sampung adalah nama daerah bagian dari kekuasaan Pemerintah Daerah kabupaten Ponorogo. Dalam perkembangannya, Sampung menjadi sebuah kecamatan yang 
membawahi beberapa desa. Pada masa dahulu, Sampung ini merupakan tempat yang dipilih oleh KH. Bukhori dan KH. Mustofa sebagai tempat tinggal dan daerahnya merupakan hutan belantara dengan pohon-pohon yang besar, tetumbuhan, semak belukar serta didalamnya terdapat bermacam-macam binatang buas. Daerah Sampung tersebut juga masih banyak terdapat bangsa lelembut 
atau makhluk halus sebagai penguasanya. Karena terkenal dengan daerah yang angker itu, maka masyarakat pada masa itu menyebut sebagai "jalmo moro jalmo mati" (barang siapa yang datang/masuk tidak akan pernah kembali lagi atau meninggal). Hal itu sangat beralasan karena setiap kali seseorang yang datang/masuk kedalam hutan tersebut maka orang itu dipastikan tidak akan pernah kembali lagi atau hilang. Sehingga, masyarakat yang akan menempati tempat atau daerah tersebut merasa "mangu-mangu" (ragu-ragu). Maka dari itu, kata "mangu-mangu" menjadi embrio lahirnya sebuah nama tempat yaitu "Mangunan". Nama Mangunan ini sebagai sebuah daerah/wilayah kecil bagian dari dukuh Pilang desa Tulung kecamatan Sampung kabupaten Ponorogo. Menurut sebuah riwayat, KH. Bukhori bukanlah orang pertama kali yang menempati Mangunan. Sebelum beliau, sudah pernah ada orang lain yang lebih dahulu membuka hutan untuk dijadikan tempat tinggal, oleh karena tidak tahan atau kuat menempatinya, maka orang tersebut pergi meninggalkan daerah itu dan menuju kearah utara.

Demi terlaksananya cita-cita dari KH. Bukhori tersebut diatas maka langkah pertama yang dilakukan beliau yaitu membangun sebuah surau sebagai tempat ibadah serta memberikan wejangan-wejangan kepada masyarakat sekitar kediaman beliau. Dan seiring berjalannya waktu karena sebuah surau sebagai tempat ibadah tersebut sudah tidak muat lagi sebagai tempat ibadah masyarakat, maka beliau mendirikan sebuah masjid dan kemudian membangun sebuah asrama pesantren untuk menampung para santri yang semakin lama semakin banyak berdatangan dari luar daerah Mangunan. Sehingga pada akhirnya sebuah masjid tersebut diberi sebutan nama AlBukhori dan Pondok pesantren Al-Bukhori, nama tersebut diambil dari nama beliau.

Perkembangan Yayasan Al-Bukhori Ponorogo sepeninggal KH. Bukhori dipegang oleh salah satu menantu beliau yaitu KH. Toyyib mulai tahun 1900 sampai dengan tahun 1944 masehi. Pada masa kepengurusan tersebut grafis kuantitas dan kualitas santri semakin menurun disebabkan KH. Toyyib pada waktu itu sebagai seorang ulama' merasa terpanggil untuk berjihad mengusir para penjajah dan imperialis barat dari bumi nusantara. Dasar dari semangat jihad dan semangat juang yang tinggi itu berlandaskan pada hadits Nabi Saw. yang berbunyi "Habbul Wa Thoni Minal Iman" artinya bahwa cinta tanah air adalah sebagian dari iman.

Pada masa kepengurusan KH. Toyyib tersebut beliau setiap hari juga memberi wejangan sekaligus gemblengan kepada para santri-santrinya. Sehingga meskipun dalam usia lanjut beliau tetap eksis memberi komando kepada para santri untuk siap maju kemedan berperang berjihad melawan penjajah dan hasil perjuangannya selama itu tidak sia-sia, satu tahun setelah wafatnya beliau melalui Ir. Soekarno dan Muh. Hatta bangsa Indonesia mendapatkan kemerdekaannya. Selanjutnya sepeninggal KH. Toyyib kepemimpinan dilanjutkan oleh anak-anak beliau, diantaranya adalah sebagai berikut:

1. KH. Abdullah Hasyim.

2. KH. Idris.

3. Ny. Hj. Isratun.

4. KH. Mahmudi.

Keempat anak-anak beliau telah tiada menghadap kehadirat Allah SWT., kemudian pada masa selanjutnya pengembangan yayasan Al-Bukhori Ponorogo dilanjutkan oleh:

1. K. Manshur Sholeh, menantu KH. Mahmudi wafat tahun 2012.

2. K. Mukrim Abdullah, putra bungsu KH. Abdullah Hasyim.

3. K. Imam Muslim, putra kedua KH. Abdullah Hasyim.

4. KH. Adnan Idris, (Putra KH. Idris) wafat tahun 2018. 
Pesantren Al-Bukhori yang terletak di dukuh Pilang desa Tulung kecamatan Sampung kabupaten Ponorogo secara kelembagaan bernaung dibawah Yayasan Al-Bukhori Ponorogo yang secara resmi terdaftar di kementerian hukum dan HAM Republik Indonesia melalui akta Yayasan bernomor AHU-0033587.AH.01.04. tahun 2015 yang ditetapkan pada tanggal 25 Desember 2015. Selain itu untuk menunjang kegiatan belajar dan mengajar santri sampai saat ini berbagai sarana dan prasarana fisik yang dimiliki oleh pesantren Al-Bukhori Ponorogo untuk mengembangkan kelembagaan adalah asrama/pondok untuk santri putra dan putri, kantor pusat, gedung Madrasah Diniyah Takmiliyah, Taman Pendidikan AlQur'an (TPQ), Madrasah Qur'an (MQ), gedung Madrasah Ibtidaiyah Ma'arif Sunan Kalijogo, gedung Sekolah Menengah Pertama Sunan Kalijaga, gedung Sekolah Menengah Kejuruan Sunan Kalijaga, Thoriqoh, Lembaga Pencak Silat Nahdhatul Ulama (LPS NU) Pagar Nusa GASMI, gedung Lembaga Kesejahteraan Sosial Anak (LKSA) Al-Bukhori, masjid, dapur umum, ruang pertemuan, laboratorium komputer, laboratorium tata busana dan lapangan olahraga, seluruh sarana diberikan kepada santri agar para santri dapat belajar lebih efektif.

Yayasan Al-Bukhori Ponorogo adalah lembaga nirlaba yang berorientasi pada dunia pendidikan dan dakwah di masyarakat. Sebagai lembaga yang muncul ditengah umat, Yayasan Al-Bukhori Ponorogo memberikan kontribusi nyata bagi umat Islam dan bangsa Indonesia agar semakin maju kedepan dan menggapai ridho Allah SWT. serta mendapat kemenangan dan kebaikan di dunia dan di akhirat kelak.

Dalam fenomena perubahan sosial-keagamaan masyarakat muslim yang terjadi di dukuh Pilang, desa Tulung, kecamatan Sampung kabupaten Ponorogo terdapat hubungan dualitas yang terjalin antara agen pencetus perubahan dengan struktur yang ada. Hubungan tersebut terwujud dalam peran agen dan struktur yang saling mempengaruhi dan terjadi dalam momentum ruang dan waktu. Hubungan tersebut diawali oleh upaya agen pencetus perubahan untuk memperbaiki kondisi sosial di lingkungan sekitar pesantren dan perubahan religiusitas masyarakat muslim di dukuh Pilang tersebut yang masyarakatnya telah lama hidup dalam kondisi kurang pemahaman terhadap ilmu agama Islam. Upaya tersebut terwujud dalam praktik sosial-keagamaan yang dilakukan oleh agen dalam tindakannya melakukan pendidikan dan pembelajaran Islam dan mengajak masyarakat dengan memberi contoh melalui tindakan tersebut. Agen juga memiliki latar belakang pengetahuan yang menjadi pemahamannya untuk melakukan rasionalisasi terhadap tindakannya jika ada pihak yang bertanya atau menentang upayanya. Upaya tersebut kemudian direspon oleh masyarakat hingga pada akhirnya mereka merasakan manfaat dari tindakannya sehingga semakin semangat dan sadar untuk berbenah.

Jika mengacu pada gagasan Giddens mengenai tiga dimensi struktural dalam praktik sosial (signifikansi, dominasi dan legitimasi) maka terjalinnya hubungan yang saling mempengaruhi antara agen pencetus perubahan dengan struktur yang ada dalam kehidupan masyarakat muslim di dukuh Pilang, desa Tulung, kecamatan Sampung kabupaten Ponorogo. Jalinan tersebut ketika agen memiliki kekuasaan sebagai pengasuh/pimpinan pesantren Al-Bukhori Ponorogo yaitu melalui skema dominasi, signifikansi dan legitimasi. Dimulai pada tahap dominasi yakni struktur yang berkaitan dengan penguasaan orang (politik) dan barang (ekonomi) melalui sarana fasilitas yang tersedia. Dominasi agen terhadap strukturnya dimulai ketika masyarakat muslim yang ada disekitar pesantren AlBukhori Ponorogo mulai melihat adanya keberhasilan dari upaya yang dilakukan oleh agen tersebut. Keberhasilan tersebut berupa jumlah santri yang terus bertambah, berdirinya 
lembaga-lembaga formal dan non formal di lingkungan yayasan Al-Bukhori Ponorogo serta pencak silat Nahdlatul Ulama' Pagar Nusa GASMI, sehingga masyarakat percaya dan mau mengikuti tindakan serta ajakan yang dilakukan oleh agen. Masyarakat yang pada mulanya menolak tindakan agen tersebut tetapi kemudian mendukungnya.

Dengan diangkatnya agen perubahan tersebut menjadi pengasuh/pimpinan pesantren Al-Bukhori Ponorogo maka telah mendominasi masyarakat, terutama masyarakat muslim di dukuh Pilang, desa Tulung, kecamatan Sampung kabupaten Ponorogo. Dominasi tersebut kemudian semakin mempermudah agen dalam melakukan perubahan sosial-keagamaan di lingkungannya karena atas kepercayaan dari masyarakat itu maka apa yang disarankan oleh agen akan selalu didukung dan dilaksanakan. Respon yang diberikan oleh masyarakat lingkungan sekitar agen juga akan bernilai positif karena posisi agen sebagai pengasuh pesantren yang mempunyai tingkat keilmuan agama Islam lebih baik serta agen telah membentuk struktur kepengurusan yang melibatkan semua anggota masyarakat di sekitarnya.

Skema dominasi terjadi ketika agen melalui tindakannya berhasil menguasai orang lain. Orang lain yang dimaksud disini adalah masyarakat yang berada di masyarakat muslim di dukuh Pilang, desa Tulung, kecamatan Sampung kabupaten Ponorogo yang menjadi domisili agen (ruang) yang mana orang lain tersebut menjadi fasilitas pendukung yang dimiliki oleh agen untuk mencapai tujuannya. Dominasi tersebut ditandai dengan semakin tingginya kepercayaan masyarakat terhadap tindakan yang dilakukan oleh agen karena menjadi pemimpin/pengasuh pesantren di lingkungannya. Dengan kekuasaan yang dimiliki oleh agen pencetus perubahan itu kemudian memiliki momentum lebih (waktu) untuk memberikan pengaruhnya dalam rangka menguasai perilaku orang lain, yakni perilaku sosial-keagamaan masyarakat muslim.

Setelah melalui skema dominasi maka hubungan antara agen perubahan dengan strukturnya berlanjut pada skema struktur signifikansi, yakni skema simbolik atau penandaan yang menyangkut penyebutan, pemaknaan dan wacana. Pada skema ini, agen perubahan melalui kesadaran diskursif yang dimilikinya mengkomunikasikan berbagai pengetahuan keagamaan yang dimiliki kepada masyarakat muslim melalui contoh tindakan dan ajakannya agar melakukan hal serupa, yakni mengenai pendidikan dan pengetahuan religiusitas dan spiritualitas dengan keinginan untuk merubah kondisi sosial-keagamaan masyarakat tersebut. Dari praktik sosial-keagamaan agen, kemudian memberi kesan tersendiri bagi masyarakat muslim sehingga memotivasi mereka untuk turut melakukan tindakan sebagaimana yang dilakukan oleh agen, terlebih dengan berdirinya lembaga formal dan non formal di sekitar pesantren Al-Bukhari Ponorogo serta pencak silat Nahdlatul Ulama' Pagar Nusa GASMI, maka praktik sosial-keagamaan yang dilakukan oleh masyarakat tetap dipertahankan. Dari hal tersebut kemudian menjadi rutinitas kehidupan sosial-keagamaan masyarakat muslim di dukuh Pilang, desa Tulung, kecamatan Sampung kabupaten Ponorogo sehingga membentuk praktik sosial-keagamaan yang baru.

Skema signifikansi pada tataran struktur masyarakat muslim tersebut terjadi setelah agen perubahan melalui kontinuitas praktik sosial-keagamaannya mampu menyebarluaskan tindakan dan menjangkau seluruh masyarakat muslim dalam lingkup ruang dan kurun waktu tertentu. Keberadaan ruang dan waktu dalam skema signifikansi pada tataran struktur masyarakat muslim tersebut menjadi unsur penting karena dalam ruang dan waktu itu kemudian masyarakat muslim tersebut mengalami reproduksi pada strukturnya sehingga mengarahkan pada terjadinya perubahan sosial-keagamaan di dukuh Pilang tersebut. 
Keberhasilan agen diawali melalui praktik sosial-keagamaannya dengan berdirinya pencak silat Nahdlatul Ulama' Pagar Nusa GASMI di pesantren Al-Bukhari Ponorogo sebagai sarana olahraga dan pengetahuan spiritualitas masyarakat muslim serta menjadi ruang agen dalam melakukan praktik komunikasi kepada masyarakat muslim dalam waktu tertentu. Dikatakan waktu tertentu karena waktu yang dibutuhkan agen untuk mendapat kepercayaan masyarakat muslim sekitar melalui tindakan yang dicontohkannya tersebut dalam proses waktu yang belum diketahui.

Setelah skema signifikansi yang terjalin melalui tindakan sosialisasi keagamaan agen kepada masyarakat muslim sekitar mengenai manfaat pencak silat Nahdlatul Ulama' Pagar Nusa GASMI di pesantren Al-Bukhari Ponorogo sebagai sarana olahraga dan pengetahuan spiritualitas telah berhasil membuat pemikiran masyarakat untuk melakukan perubahan maka hubungan yang terjalin antara agen dengan struktur berlanjut pada fase legitimasi yaitu struktur yang menyangkut pembenaran atas peraturan normatif yang ada dalam tata hukum. Giddens menyebut struktur legitimasi tersebut sebagai sistem kaidah moral dan pada fase legitimasi dualitas agen dengan struktur berlanjut pada tataran pembenaran oleh struktur masyarakat muslim secara lebih luas. Artinya tidak hanya masyarakat yang berada di sekitar tempat tinggal agen saja yang membenarkan upaya agen tersebut tetapi masyarakat muslim diluar desa Tulung atau masyarakat diluar kabupaten Ponorogo juga ikut mendukung upaya agen dalam melakukan perubahan sosial-keagamaan tersebut.

Dukungan dari seluruh masyarakat muslim sekitar tersebut tidak muncul karena adanya upaya agen saja tetapi karena adanya dukungan dominasi struktur dari pihak pemerintahan desa Tulung dan Pemda Ponorogo yang turut melakukan legitimasi terhadap upaya agen itu. Legitimasi yang diberikan oleh pihak pemerintahanan desa Tulung dan Pemda Ponorogo tersebut berupa dukungan terhadap agen melalui berbagai peraturan dan status hukum yang berkaitan dengan pencak silat Nahdlatul Ulama' Pagar Nusa GASMI di pesantren Al-Bukhari Ponorogo. Selain itu, dukungan terhadap upaya yang diawali oleh agen tersebut diperkuat dengan dibentuknya struktur kepengurusan pencak silat Nahdlatul Ulama' Pagar Nusa GASMI Ponorogo yang bertugas untuk melakukan pembinaan dan sosialisasi terhadap seluruh anggotanya yang terdiri dari anggota masyarakat di desa Tulung dan sekitarnya. Legitimasi yang diberikan oleh pihak pemerintahanan desa Tulung dan Pemda Ponorogo tersebut sangat dibutuhkan agar mendapatkan kepercayaan dan dukungan dari masyarakat muslim sekitar bahwa pencak silat Nahdlatul Ulama' Pagar Nusa GASMI Ponorogo sebagai organisasi yang didukung pemerintah dan bukan sebagai organisasi liar atau organisasi terlarang karena tidak ada legalitas dari pemerintah.

Pencak silat Nahdlatul Ulama pagar nusa merupakan salah satu aliran pencak silat yang didirikan oleh para ulama dan para kyai yang dinaungi oleh salah satu organisasi masyarakat besar di Indonesia yakni Nahdlatul Ulama terdapat di seluruh Indonesia, gerakan seninya yang khas dan indah membuat pencak silat ini banyak diminati oleh beberapa kalangan, baik anak-anak, remaja, dewasa, hingga orang tua. Selain itu pencak silat yang didirikan oleh persatuan atau himpunan para tokoh-tokoh kyai di pondok pesantren, sehingga ajaran-ajaran atau muatan-muatan yang diberikan tidak meninggalkan kegiatan keagamaan atau relegius dan spiritualitas. Melalui beberapa kegiatan keagamaan yang dilaksanakan didalam latihannya, yang menjadi salah satu kekuatan batin atau energi positif tersendiri. Kegiatan ini dimaksutkan guna untuk melatih diri dan senantiasa takut akan berbuat dosa maupun berbuat ingkar, selalu melakukan kebaikan, menahan kekuatan amarah atau hawa nafsu sehingga terhidar dari kemungkaran dan selamat dari godaan setan. 
Pencak silat Nahdlatul Ulama' pagar nusa GASMI dalam meningkatkan spiritualitas masyarakat muslim di dukuh Pilang desa Tulung kecamatan Sampung kabupaten Ponorogo didalamnya diajarkan akhlaqul karimah, amar ma'ruf nahi mungkar, yang berasaskan aswaja (ahlusunnah waljamaah), mengalahkan amarah dan mempertimbangkan segala sesuatunya secara matang, yakni karakter yang tegas, berfikir terlebih dahulu sebelum bertindak dan menjahui kemungkaran, selain itu diajarkan pula untuk membela diri, gerakan lincah seni bertarung yang indah, selain itu diajarkan kegiatan-kegiatan spiritualitas yang diantaranya bertawasul, berdoa sebelum latihan agar diberikan keselamatan dan ilmu bermanfaat, berdzikir, sholat malam, dan berpuasa. Hal tersebut adalah yang biasa diajarkan oleh para kyai-kyai dulu dan turun-temurun diteruskan hingga sampai sekarang, selain berlatih fisik di pagar nusa juga berlatih ilmu kebatinan, bermuhasabah diri, sehingga merasa ilmu yang diajarkan setiap hari belum seberapa, kekuatan yang hak hanyalah pemberian dari Allah Swt. dan semata-semata mencari ridho Allah Swt., seperti apa yang sudah di paparkan oleh Wahyudi selaku pembina pencak silat Nahdlatul Ulama' Pagar Nusa GASMI di Pesantren Al-Bukhori Ponorogo mengatakan bahwa:

"di pagar nusa Al-Bukhori Ponorogo juga diajarkan ilmu kebatinan, bermuhasabah diri, selain itu diajarkan kegiatan-kegiatan spiritualitas yang diantaranya bertawasul, berdoa sebelum latihan agar diberikan keselamatan dan ilmu bermanfaat, berdzikir, sholat malam, dan berpuasa biasanya hal itu dilaksanakan saat briefing, juga diadakan istighosah sebelum latihan, dan waktu bulan ramadhan pada sore hari diadakan mengaji kitab, lalu buka puasa dan dilanjut solat terawih secara berjamaah, setelah itu baru dilaksanakan latihan bersama. Ketika akan diakhiri latihan atau penutupan menjelang hari raya Idul Fitri diadakan ziarah wali”

Dari pemaparan diatas dapat dilihat atau didapati bahwasanya memang benar-benar ada didalam pencak silat Nahdlatul Ulama' Pagar Nusa GASMI di Pesantren Al-Bukhori dukuh Pilang desa Tulung kecamatan Sampung kabupaten Ponorogo kegiatan atau muatanmuatan yang sifatnya berbentuk nilai-nilai spiritualitas, dari kegiatan-kegiatan tersebut secara pelan-pelan pelatih/pengurus mencoba memasukkan nilai-nilai yang sifatnya membentengi diri, berbuat baik kepada sesama sebagai bagian dari akhlaknya, sehingga terhindar dari pergaiulan yang salah. Selain kegiatan berlatih fisik yang diajarkan secara rutin, terdapat juga latihan yang sifatnya mendekatkan diri kepada Allah SWT., yang tidak jauh dari amalan-amalan warga nahdliyin pada umumnya diantaranya berdoa sebelum latihan, bertawasul, berdzikir, istighosah, berpuasa, mengaji, pesantren kilat, serta berziarah kubur.

Pencak silat Nahdlatul Ulama' Pagar Nusa GASMI di pesantren Al-Bukhori dukuh Pilang desa Tulung kecamatan Sampung kabupaten Ponorogo dalam meningkatkan spiritualitas ini bukan hanya sekedar tempat silaturahmi tetapi juga sebagai bentuk pelaksanaan kegiatan-kegiatan yang sudah ada dan dijadwalkan di pesantren Al-Bukhori Ponorogo itu sendiri. Di pesantren Al-Bukhori Ponorogo ini bukan hanya dijadikan tempat untuk berlatih ataupun untuk menimba ilmu, namun dalam kegiatan pencak silat Nahdlatul Ulama' Pagar Nusa GASMI di pesantren Al-Bukhori Ponorogo mempunyai peran yang sesuai dengan wawancara yang peneliti lakukan serta sesuai apa yang dikatakan oleh Dimas Bimantoro sebagai bidang kepelatihan pencak silat Nahdlatul Ulama' Pagar Nusa GASMI di Pesantren Al-Bukhori Ponorogo bahwa:

"Pagar Nusa GASMI di Pesantren Al-Bukhori juga bisa untuk tempat sharing atau curhat, bermusyawarah, berdiskusi bareng, dan juga bisa dikatakan 
menjadi rumah kedua untuk semua anggota yang ada di sini, dan namanya perkumpulan atau perguruan itu adalah tempat segala-segalanya untuk semua anggota yang ikut serta dalam pencak silat ini..."

Begitu juga sesuai wawancara dengan Wahyudi selaku pembina pencak silat Nahdlatul Ulama' Pagar Nusa GASMI di Pesantren Al-Bukhori Ponorogo mengatakan bahwa:

"pencak silat Nahdlatul Ulama' Pagar Nusa GASMI di Pesantren Al-Bukhori ini merupakan tempat untuk para pemuda dan pemudi nyantri, guna untuk menimba ilmu agama dan berlatih keterampilan (latihan jurus pencak silat) pada seorang guru atau pelatih yang dipercaya memiliki ilmu dan keterampilan yang tinggi..."

Setelah observasi yang bertempat di Pesantren Al-Bukhori Ponorogo terkait dengan beberapa peran pencak silat Nahdlatul Ulama' Pagar Nusa GASMI maka penulis dapat menyimpulkannya sebagai berikut:

1. Meredam emosi

Peran yang pertama dalam kegiatan pencak silat Nahdlatul Ulama' Pagar Nusa GASMI di pesantren Al-Bukhori dukuh Pilang desa Tulung kecamatan Sampung kabupaten Ponorogo ini yaitu meredam emosi. Sebagaimana dalam wawancara yang dilakukan penulis dalam hal ini terkadang beberapa anggota atau santri pencak silat Pagar Nusa jika sedang marah atau sedang merasakan hati yang sedang tidak enak, anggota atau santri pencak silat itu pergi ke tempat latihan atau berkunjung ke kediaman pelatih atau pembina, berkonsultasi, atau sekedar bermain di tempat latihan itu agar amarah yang sedang dihadapinya itu tidak berujung kepada orang di sekitarnya. Dalam hal ini biasanya terdapat pada anggota atau santri yang berkisar umur 13-15 tahun, dimana dalam umur ini biasanya remaja jika sedang marah terkadang melakukan hal yang tidak baik tetapi karena adanya perguruan pencak silat Nahdlatul Ulama' Pagar Nusa GASMI di pesantren Al-Bukhori dukuh Pilang desa Tulung kecamatan Sampung kabupaten Ponorogo bisa sedikit menjadi tempat untuk meredam amarah.

2. Menyalurkan minat dan bakat

Perguruan pencak silat Nahdlatul Ulama' Pagar Nusa GASMI di pesantren AlBukhori dukuh Pilang desa Tulung kecamatan Sampung kabupaten Ponorogo tersebut para santri atau para remaja di luar pesantren dapat menyalurkan minat atau bakat yang terpendam dalam hal olahraga atau beladiri. Pada usia-usia remaja, terkadang mempunyai minat atau bakat dalam bidang tersebut, tetapi ada kalanya mereka malu atau tidak berani dalam mengeluarkan minat atau bakat tersebut. Maka oleh sebab itu, adanya perguruan atau kegiatan pencak silat Nahdlatul Ulama' Pagar Nusa GASMI di pesantren Al-Bukhori dukuh Pilang desa Tulung kecamatan Sampung kabupaten Ponorogo dapat difungsikan sebagai penyalurkan minat dan bakat. Contohnya jika remaja mempunyai minat dalam berlatih pencak silat atau jurus-jurus silat dapat menyalurkannya jurus-jurus silatnya diajang perlombaan.

3. Membentuk kesabaran

Kegiatan pencak silat Nahdlatul Ulama' Pagar Nusa GASMI di pesantren AlBukhori dukuh Pilang desa Tulung kecamatan Sampung kabupaten Ponorogo ini yaitu membentuk kesabaran. Dalam fungsi yang ada dalam pencak silat Nahdlatul Ulama' 
Pagar Nusa, bukan hanya mempelajari tentang jurus-jurus silat saja, tetapi juga dalam pembinaan akhlaknya. Salah satu pembinaan akhlak yang diajarkan yaitu membentuk kesabaran. Dalam hal ini, belajar jurus-jurus silat tidak bisa terburu-buru dalam belajar, harus dengan pelan-pelan, teliti, dan paham dengan jurus yang diajarkan oleh pelatih, hal tersebut dapat membentuk kesabaran pada diri anggota atau santri karena setiap apa yang dipelajarinya haruslah teliti dan memahami dengan sungguh-sungguh.

4. Menjalin silaturahmi

Dalam kegiatan pencak silat Nahdlatul Ulama' Pagar Nusa GASMI di pesantren Al-Bukhori dukuh Pilang desa Tulung kecamatan Sampung kabupaten Ponorogo ini yaitu menjalin silaturahmi, tempat kegiatan pencak silat Nahdlatul Ulama' Pagar Nusa bisa menjadi sarana silaturahmi antara pelatih maupun anggota, para pelatih yang telah senior maupun anggota, ataupun guru besar juga. Jadi dalam hal fungsi keempat ini tempat kegiatan pencak silat Nahdlatul Ulama' Pagar Nusa berfungsi silaturahmi, yaitu dengan adanya tempat tersebut terdapat hubungan antara pembina, ketua ranting, para pelatih atau guru besar dan bidang-bidang kepengurusan tidak terputus.

5. Menjadi tempat bertukar pikiran

Kegiatan pencak silat Nahdlatul Ulama' Pagar Nusa GASMI di pesantren AlBukhori dukuh Pilang desa Tulung kecamatan Sampung kabupaten Ponorogo yaitu sebagaimana hasil wawancara penulis dengan salah satu pelatih bahwa kegiatan pencak silat Nahdlatul Ulama' Pagar Nusa GASMI di pesantren Al-Bukhori dukuh Pilang desa Tulung kecamatan Sampung kabupaten Ponorogo itu sendiri bukan menjadi sarana untuk belajar ilmu bela diri saja tetapi bisa menjadi tempat sharing/curhat serta bisa dilakukan untuk tempar berdiskusi bersama antara pelatih dan anggota pencak silat.

\section{KESIMPULAN}

Dari hasil penelitian peran pesantren Al-Bukhori Ponorogo dalam meningkatkan religiusitas masyarakat muslim pedesaan melalui pencak silat Nahdlatul Ulama' Pagar Nusa GASMI, maka penulis dapat menyimpulkan sebagai berikut Peran pesantren Al-Bukhori Ponorogo dalam meningkatkan religiusitas masyarakat muslim di dukuh Pilang desa Tulung kecamatan Sampung kabupaten Ponorogo adalah sebagai berikut:

a. Pencetus perubahan untuk memperbaiki kondisi sosial di lingkungan sekitar pesantren.

b. Pencetus perubahan religiusitas masyarakat muslim di dukuh Pilang.

c. Sebagai sistem Pendidikan Islam dan pembelajaran agama Islam.

d. Sebagai pemberi contoh teladan dalam praktik sosial-keagamaan.

e. Sebagai pemberi petunjuk, pertimbangan atau nasihat dalam agama Islam.

f. Sebagai lembaga dakwah di masyarakat.

g. Sebagai tempat mencari ilmu agama Islam dan tempat mengabdi.

h. Sebagai tempat mempersiapkan generasi-generasi muslim yang handal, berpotensi, berprestasi dan berkwalitas.

i. Sebagai tempat pengajaran spiritual masyarakat muslim.

j. Sebagai tempat santunan anak yatim/miskin.

k. Sebagai tempat pemberi beasiswa pendidikan bagi anak yatim/miskin. 
Peran Pencak Silat Nahdlatul Ulama' Pagar Nusa GASMI dalam meningkatkan spiritualitas masyarakat muslim di dukuh Pilang desa Tulung kecamatan Sampung kabupaten Ponorogo diantaranya adalah sebagai berikut:

a. Nilai akidah diwujudkan dengan penanaman beberapa perilaku diantaranya berdoa sebelum memulai kegiatan, himbauan untuk melaksanakan kewajiban sebagai seorang muslim, himbauan untuk berdzikir dan bersholawat kepada nabi SAW. dan penyampaian pesan tidak ada kemenangan kecuali dengan pertolongan Allah SWT.

b. Nilai syariat diwujudkan dengan penanaman beberapa perilaku diantaranya disiplin saat latihan dan himbauan untuk melakukan amalan-amalan sunnah.

c. Nilai akhlak diwujudkan dengan penanaman beberapa perilaku diantaranya ta'dzim, persaudaraan (ukhuwah), persamaan (al-musawah), keadilan, rendah hati (tawadhu'), tepat janji (al-wafa'), lapang dada (insyiraf), dapat dipercaya (alamanah), perwira ('iffah atau ta'affuf) dan dermawan (al-munfiqun).

Faktor-faktor pendukung dan penghambat dalam meningkatkan religiusitas masyarakat muslim di dukuh Pilang desa Tulung kecamatan Sampung kabupaten Ponorogo melalui Pencak Silat Nahdlatul Ulama' Pagar Nusa GASMI adalah sebagai berikut:

a. Faktor-faktor pendukung diantaranya adalah keberhasilan program pelatihan, anggota pencak silat merasa nyaman dalam berlatih, para pelatih dan pengurus memberikan motivasi dan pemahaman tentang spiritual kepada setiap anggota, fasilitas pelatihan dalam proses bertahap, adanya legalitas dari pemerintah serta para pelatih senior memberikan pemahaman tentang pencak silat Nahdlatul Ulama' Pagar Nusa GASMI setiap diadakan latihan bersama.

b. Faktor-faktor penghambat diantaranya adalah anggota yang malas berlatih, anggota yang kesulitan dalam memahami materi pelatihan, anggota belum mengaplikasikan hasil latihan di kehidupan sehari-hari, pengaruh budaya luar, sarana dan prasarana kurang mendukung, terkendala waktu pelatihan, perkembangan zaman atau globalisasi, adanya organisasi masyarakat, badan otonom atau perguruaan silat lainnya.

\section{DAFTAR PUSTAKA}

Agustina, Sri. Riwayat Hidup Kh. Muhammad Abdullah Maksum Jauhari Kediri Jawa Timur (Tahun 1944-2003). Tesis tidak diterbitkan. Surabaya: Fakultas Adab IAIN Sunan Ampel Surabaya. 2009.

Andriani, Irena Fitri. Fungsi Padepokan Pencak Silat Pagar Nusa Dalam Pembinaan Akhlaqul Karimah Kaum Remaja Desa Dwi Warga Tunggal Jaya Unit II Kecamatan Banjar Agung Kabupaten Tulang Bawang. Tesis tidak diterbitkan. Lampung: Fakultas Dakwah Dan Ilmu Komunikasi UIN Raden Intan Lampung. 2018.

Anonim, Pagar Nusa Gasmi Ponorogo, (Online), (https://gasmicabangponorogo.blogspot.com/2020/06/pagar-nusa-gasmi-cabangponorogo.html.), diakses 29 Maret 2021.

Arikunto, Suharsimi. Prosedur Penelitian Suatu Pendekatan Praktik. Jakarta: Rineka Cipta. 2006. 
Asyifak, Hikmah. Peran Pondok Pesantren Dalam Meningkatkan Moralitas Keagamaan Masyarakat Pedesaan: Studi Kasus Pondok Pesantren Mamba'ul Ma'arif Denanyar Jombang. Tesis tidak diterbitkan. Surabaya: Fakultas Tarbiyah Dan Keguruan UIN Sunan Ampel Surabaya. 2016.

Ayu, Noftafiani Putri. Perkembangan Pencak Silat NU Pagar Nusa Di Kecamatan Singkut Kabupaten Sarolangun Tahun 1998-2015. Artikel, (Online), (https://repository.unja.ac.id/3166/), diakses 22 Maret 2021.

Danim, Sudarwan. Menjadi Peneliti Kualitatif . Cet. 1. Bandung: Pustaka Pelajar. 2002.

Danim, Sudarwan. Menjadi Peneliti Kualitatif . Bandung: Pustaka Setia. 2002.

Fatich, Sabita Nurul. Peran Pondok Pesantren Darul A'mal Terhadap Peningkatan Nilai Religius Masyarakat Mulyojati 16 B Metro Barat. Tesis tidak diterbitkan. Metro: Fakultas Ushuluddin IAIN Metro. 2018.

Galba, Sindu. Pesantren Sebagai Wadah Komunikasi. Jakarta: Rinneka Cipta. 2004.

Giddens, Anthony. Problematika Utama dalam Teori Sosial; Aksi, Struktur, dan Kontradiksi dalam Analisis Sosial. Terjemahan Dariyatno, 2009. Yogyakarta: Pustaka Pelajar. 1979.

Giddens, Anthony. Suatu Pengantar. Terjemahan. B. Herry-Priono, 2010. Jakarta: Kepustakaan Populer Gramedia. 2002.

Giddens, Anthony. The Constitution of Society: Teori Strukturasi Untuk Analisis Sosial Masyarakat. Terjemahan Maufur dan Daryanto, 2010. Jakarta: Pustaka Pelajar. 2011.

Badan Pengembangan dan Pembinaan Bahasa. Kamus Besar Bahasa Indonesia (KBBI), (Online), (https://kbbi.kemdikbud.go.id/), diakses 16 Februari 2021.

Lesmana, Ferry. Panduan Pencak Silat 1. Pekanbaru: Zanafa Publishing. 2012.

Lesmono, Hartono. Teori Komunikasi 1 Structuration Theory (Teori Strukturasi), (Online), (https://slideplayer.info/slide/12891808/), diakses 16 Februari 2021.

Liana, Corry. Pagelaran Tarung Bebas Pencak Dor Kediri Sebagai Upaya Pelestarian Bela Diri Pencak Silat Tahun 1960-2017, 6. (4), (Online), (https://ejournal.unesa.ac.id/index.php/avatara/article/view/26341), diakses 18 Maret 2021.

Naja, M. Sabilun. Internalisasi Nilai-Nilai Aqidah Akhlak Kepada Peserta Didik Melalui Pencak Silat Nahdlatul Ulama Pagar Nusa Di SMP Bina Bangsa Siwalankerto Surabaya. Tesis tidak diterbitkan. Surabaya: Fakultas Tarbiyah Dan Keguruan UIN Sunan Ampel Surabaya. 2020.

Narbuko, Cholid dan Achmadi, Abu. Metode Penelitian. Jakarta: Bumi Aksara. 2002. 
Nizar, Samsul. Sejarah Sosial \& Dinamika Intelektual Pendidikan Islam di Nusantara. Jakarta: Kencana. 2013.

Nugroho, Wahyu. "Peran Pondok Pesantren dalam Pembinaan Keberagamaan Remaja". Jurnal Pendidikan. Ponpes al-Hasan Salatiga. 2016.

Safi'I, M. Ilyas. Nilai-Nilai Pendidikan Agama Islam Dalam Kegiatan Ekstrakurikuler Pencak Silat Pagar Nusa Di Pondok Pesantren Agro Nuur El-Falah Salatiga. Tesis tidak diterbitkan. Salatiga: Fakultas Tarbiyah Dan Ilmu Keguruan IAIN Salatiga. 2019.

Saleh, Abdul Rahman. Pendidikan Agama dan Keagamaan: Visi, Missi, Dan Aksi. Jakarta: PT. Gema Windu Panca Perkasa. 2000.

Sofyana, Ardian. Pencak Silat Nahdlatul Ulama Pagar Nusa Di Pondok Pesantren Al-Hanif Bagelen Purworejo Tahun 1994-2016 M. Tesis tidak diterbitkan. Yogyakarta: Fakultas Adab Dan Ilmu Budaya UIN Sunan Kalijaga Yogyakarta. 2018.

Sugiyono. Metode Penelitian Kualitatif Kuantitatif dan R\&D. Bandung: Alfabeta. 2009.

Sukardi. Metodologi Penelitian Pendidikan. Jakarta: Bumi Aksara. 2004.

Wahid, Abdurrahman. Menggerakkan Tradisi: Esai-Esai Pesantren. Jogjakarta: LKIS. 2001.

Yakup, M. Pondok Pesantren dan Pembangunan Masyarakat Desa. Bandung: Angkasa. 1984.

Yusuf, Choirul Fuad et al. Pesantren Dan Demokrasi Jejak Demokrasi Dalam Islam. Jakarta: Titian Pena. 2010. 